\title{
What happened when the Americans took over Britain's electricity industry? Exploring trans- national sector effects on employment relations
}

\section{Trevor Colling \& Ian Clark}

To cite this article: Trevor Colling \& lan Clark (2006) What happened when the Americans took over Britain's electricity industry? Exploring trans-national sector effects on employment relations, The International Journal of Human Resource Management, 17:9, 1625-1644, DOI: 10.1080/09585190600878469

To link to this article: https://doi.org/10.1080/09585190600878469

\section{曲 Published online: 17 Feb 2007.}

Submit your article to this journal $₫$

山 Article views: 89

Citing articles: 4 View citing articles $\longleftarrow$ 


\title{
What happened when the Americans took over Britain's electricity industry? Exploring trans-national sector effects on employment relations
}

\author{
Trevor Colling and Ian Clark
}

\begin{abstract}
Pressures stemming from the country of origin are seen increasingly as the single most important influence on multinational companies, and American managements are famed particularly for their marked preferences for non-unionism and for pay systems linked to performance. The dramatic inflow of American investment into the British electricity industry from 1996 onwards provides an opportunity to observe the development of these influences. In fact, employment relations reform was not driven by the concerns of American owners to any significant degree, but tended to follow patterns already very well established in the utilities sector in the UK. This can only be understood in the context of similar developments in sector-level governance in both countries, and the processes through which this drove international strategies at higher levels, affecting investment and organizational structure.
\end{abstract}

Keywords Multinationals; industrial relations; privatization; regulation; country-oforigin; sector.

\section{Introduction}

Developments in the electricity supply industry over the past decade provide important insights into the behaviour of multinational companies in Europe. Substantial inward investments by American companies in the mid-1990s might be expected to have generated important consequences for employment relations. Pressures stemming from the country of origin are seen increasingly as the single most important influence on multinational companies (Ferner, 1997; Harzing and Sorge, 2002). American managements are famed generally for their marked preferences for non-unionism and for pay systems linked to performance. In the UK electricity supply industry (ESI), with its traditions of highly structured, seniority-based pay systems and established patterns of unionization (see Colling, 1991; Ferner and Colling, 1993), the potential scope for reform was immense. The managerial infrastructure of American multinationals facilitates the international transfer of such processes and the sheer weight of American investment in the UK at the time arguably would encourage transfer by providing networks of like-minded companies across the industry.

Trevor Colling, Industrial Relations and Organizational Behaviour Group, Warwick Business School, University of Warwick, Coventry CV4 7AL, UK (e-mail: Trevor.Colling@WBS.ac.uk); Ian Clark, International Management and Organization, Birmingham Business School, University House, Birmingham B15 2TT, UK (e-mail: I.Clark@bham.ac.uk).

The International Journal of Human Resource Management ISSN 0958-5192 print/ISSN 1466-4399 online (C) 2006 Taylor \& Francis

http://www.tandf.co.uk/journals

DOI: $10.1080 / 09585190600878469$ 


\section{The International Journal of Human Resource Management}

But findings discussed here fail to discover strong patterns of country-of-origin influence upon employment relations. There were few attempts to impose 'American' styles of management, either directly (through expatriate managers) or indirectly through cultural or bureaucratic mechanisms. Similar organizational structures were adopted to those prevailing in analogous UK-owned companies and these permitted significant discretion to businesses and to their generally British managers. Although change was apparent in employee relations procedures and cultures, this tended to follow patterns emerging industry wide in the UK.

The paper finds significant but multi-levelled sector effects conditioning the orientation of managers to their newly acquired British operations. They did not necessarily impact directly on employment relations, however. Rather they combined in specific ways to structure 'upstream' strategic choices, about what to produce and where, and it is these that influenced approaches to workforces.

\section{Multinational companies, institutional settings and the role of sector}

Multinational companies develop first within their own national contexts and institutional differences between geographically specific 'business systems' necessarily condition strategies and structures: 'we think it would be better to describe multinationals as national firms with international operations' (Harzing and Sorge, 2002: 206). Such is the logic underpinning streams of academic and policy literature premised on the idea of national 'models' (see Coates, 2001; Hall and Soskice, 2001; Whitley, 1992, 2001). These systems need not be understood as monoliths. New institutional theory provides the tools with which to explore different 'organizational fields', including sectors, and the ways in which they interact to modulate behaviour (DiMaggio and Powell, 1983). Difficulties arise when trying to move above the national level of analysis to explore firm behaviour across borders. National institutional factors remain highly visible at this level, but the analytical purchase of sector effects tends to be obscured.

The 'institutionalist' approach comprises a variety of perspectives and approaches but at their heart is the contention that social groups adapt their behaviour to the regulatory norms and assumptions generated by the interaction of agencies. These are not entirely unchanging, and some institutionalists are especially interested in what happens during moments of crisis or 'shock', but they are sufficiently durable to provide a predictable basis for social and economic exchange. The precise form taken by these institutions, and the terms upon with they interact, vary between national contexts. As a consequence, it has become common to group national economies, according to how prominent a role is assumed by state agencies and the degree to which they co-ordinate economic activity (e.g. Hall and Soskice, 2001; Whitley, 2001). Institutional settings thus condition differences in the nature of the firm. For example, how far the ownership of firms is separated from managerial control and the degree to which firms are narrowly specialized or diversified in unrelated business lines. They may also influence choices over managerial control systems within the firm. The management of industrial relations, work organization and job design may typically be centralized or devolved to local managers, according to the content of statutory regulation and the level of social regulation through collective bargaining.

In approaching their investments abroad, multinational companies draw deeply on the paradigm assumptions influencing their home operations (Edwards and Ferner, 2002; Ferner, 1997). The force of such home country influence is especially marked in research into American multinational companies. Studies show repeatedly that, relative to those of other national origin, American multinationals deploy highly centralized and formalized 
management systems (e.g. Harzing, 1999; Negandhi, 1986; Young et al., 1985; Yuen and Kee, 1994). On HR policy specifically, Ferner et al. (2004) found that centralization impacted particularly on approaches to three areas. First, worldwide guidelines were most widespread on the issue of pay. The centre tended to establish norms in relation to grading, pay bands and pay levels. Performance-related elements were also almost uniformly evident, though these did not always extend throughout the workforce. Second, whether linked to pay or not, performance measures played a critical role in the subsidiaries, feeding often into decisions about dismissal and redundancy. Reflecting the American 'employment-at-will' business philosophy, some firms had introduced 'forced distributions' in which specified proportions of employees had to be placed in highest and lowest performing categories, with the lowest falling vulnerable to dismissal. Finally, there was substantial evidence of deep-seated opposition to unions, particularly at corporate level, and a preference for non-unionism.

These researchers and others, though, have emphasized the need for sensitive interpretation, to acknowledge the interaction of home country influence with other pressures. Much of the prevailing literature on multinational companies explores the balance between aggregated pressures exerted from the respective business systems, those from the home country of the firm and those encountered in the host country in which operations have been established (see Muller-Camen et al., 2001). It seems that, 'national origin shapes and constrains the actions of these actors but leaves scope for them to draw on practise operating in other countries' (Edwards and Ferner, 2002: 100). For example, while confirming predicted patterns of centralization on some issues (above), Ferner et al. (2004) found a constantly shifting balance between central control of HR policy and the assertion of local autonomy. Hall et al. (2003) discovered complex responses to requirements to establish European Works Councils (EWCs). American firms generally expressed the kind of opposition that might be predicted from the homecountry perspective, but there was significant variation between firms in the approaches eventually adopted. A range of structural and agency factors stemming from the nature of the business and international composition of the firm ameliorated the influence of national origin in these cases (Marginson et al., 2004).

Findings of this kind suggest that institutional pressures beneath the national level might interact with host and home country factors. The idea of including sector as an influence has considerable intuitive appeal, since it clearly conditions developments within national contexts. Findings on pay and working time in Britain reveal strong sectoral patterns for example (Arrowsmith and Sisson, 1999).

'New institutionalist' analysis offers some useful conceptual tools, linking the nature of influence with the characteristics of 'organizational fields' which might include sector (DiMaggio and Powell, 1983). Coercive isomorphism occurs when organizations are compelled to adopt structures or rules by external bodies. At sector level, typically these will be state-level organizations, although constraints may also be exerted by employers associations and industry-wide collective bargaining, where this exists (Hollingsworth and Streek, 1994). Mimetic isomorphism tends to happen in environments where external pressures provide no clear or single set of requirements and relative uncertainty encourages firms to copy initiatives that have been implemented successfully by market leaders. Finally, normative isomorphism is driven by workforces, particularly those governed by technical or professional protocols that extend beyond the firm.

The critical difficulty in exploring sector effects, however, comes when the level of analysis moves from national to trans-national sector effects. One problem is that their depth and definition vary considerably and allegiances across boundaries may be very weak in some industries. Evidence of sector-level convergence is apparent in relatively 


\section{The International Journal of Human Resource Management}

co-ordinated and integrated sectors, like civil aviation for example (Martinez-Lucio et al., 2001). But cross-border regulation is rarely as developed as this. In most sectors, the extent to which production takes place, and the way that the product and production process are regulated, remains a matter for national institutions; hence the common finding that, 'institutional differences at the national level cause persistent heterogeneity among organisations across countries, even if they operate in the same industry and are subject to the same external influences' (Woywode, 2002: 497, emphasis added). By commission and omission, researchers on multinational companies have often relegated sector to the status of secondary influence, conditioned by home or host country factors: 'without denying that regional or sectoral institutions matter to firm behaviour ... many of the most important institutional structures... are the preserve of the nation-state' (Hall and Soskice, 2001: 4).

A number of questions are raised by this collection of issues. Under what circumstances are sector effects communicated trans-nationally? What consequences do they carry for the management of employment? And how are these influenced by the structural and normative frameworks provided by national business systems? Our central argument here is that sector effects do not necessarily operate directly upon employment systems. Analysis must capture the complexity of environmental forces shaping firmlevel responses. Using the terminology of the strategic choice literature, we distinguish between third-, second- and first-order effects. Decisions over employment issues are downstream, or third order, and are made subject to second-order decisions (over organizational and management structures) and first-order ones (over what to produce and where). In the discussion that follows, this framework is applied to the conditions prevailing in the UK electricity industry over the past decade.

\section{Methodology}

For those seeking to explore sector effects, there are good reasons to expect to find them in the electricity industry. Few of the definitional or boundary problems noted above apply here and companies generally have a strong and undiluted identity as a consequence. Cohesion is explained by the presence at national level of all three of the principal governance methods (Hollingsworth and Streek, 1994). At the lowest level, community identity is reinforced by the fact that electricity is a network industry characterized by strong inter-dependence between companies. Distribution networks to customers are only as effective as the transmission and generation systems that supply them, and so on. At the highest level of governance, electricity supply is vital to the industrial infrastructure of any single country, and this fosters high public policy interest and sustained regulatory attention by state agencies (Pendleton, 1997). The ready acknowledgement of shared interests, and a need to co-ordinate responses to government, has given rise to an intermediate form of governance, formally constituted employers associations. Since many of these features are inherent in the industry, they are more or less common across national boundaries. In most developed economies across the world, for example, 'it has been the norm for public ownership to prevail' (McGowan, 1994: 36). These factors continue to buttress the sector's boundaries and internal cohesion.

The evidence considered here is drawn from a multi-method study of changes in the British electricity supply industry conducted as part of a broader investigation of employment practice within multinational companies. ${ }^{1}$ Documentary evidence from both the UK and the USA is drawn upon; sources included government departments, regulatory authorities and electricity companies themselves. In addition, interviews were 
conducted with ten trade union officials in the UK. Qualitative interview data are a particularly appropriate way to explore the issues at hand here since they permit exploration beyond surface detail of employment practice to the processes through which changes transpired and, particularly important, the source of the impetus behind them. Respondents were drawn from the three principal unions, the Engineers' and Managers' Association (EMA, now part of PROSPECT); the Amalgamated Engineering and Electrical Union (AEEU, now part of AMICUS), and UNISON. Although other unions are recognized, these together represent the bulk of engineering, craft and administrative occupations within the electricity industry. Three of the officers involved had extensive national responsibilities, including contacts at executive level with British and American companies. Others were selected on the basis of their company specific experiences in American-owned electricity companies in the generating and distribution areas. Access to branch-level actors was facilitated in one union through attendance at a forum of activists from a range of US-owned electricity companies.

There are important limitations to the data. In particular, union sources are not matched by others from managers of American-owned companies. Access was sought to a number of companies without success. This is consequential because, while union officers may be able to report and infer international pressures for change, only managers can interpret them directly. However, the absence of direct management data is mitigated to some extent by the fact that all three unions had managers in membership throughout the periods covered and there was strong evidence of closely reciprocal information flows between management level members and their unions. Union officers were able to share with us company documentation that came originally from sources in management positions.

\section{First-order effects: patterning international investment and disinvestment}

In this section we explore the developments in the electricity sector in America and in Britain that structured first-order strategic decisions over what to produce and where. Reregulation in the two countries came to provide strong incentives for international investment. Beginning in the mid-1990s, an Anglo-American axis emerged, manifest first in increasing American ownership of UK electricity companies and later in UK companies investing in the USA (Gow, 2000; Heller, 2001). American acquisitions of distribution companies alone totalled $\$ 25$ billion dollars and accounted for 20 per cent of all inward investment in 1995 (White, 1996: 4). In generation, the combined stake of just three American companies (Texas Utilities, Edison and AES) grew to 11.2 per cent by 1999 (Gow, 1999).

Critically, the nature of the companies involved, and of the investments they made, conditioned their approaches towards lower-order strategies governing subsidiary management and employment relations. Explaining these developments requires exploration of push factors operating in the USA and pull factors attracting investors to the UK. This constellation of factors proved to be ephemeral; highly favourable investment climates were to change dramatically, resulting in retrenchment and divestment among new American owners.

Factors pushing American firms towards the UK

Increased momentum in electricity industry restructuring By the mid-1990s, a restructuring agenda for the American electricity industry had gathered significant momentum (EIA, 2000c). The main contours of reform were becoming clear and the 200 or so Investor Owned Utilities (IOUs) began to face serious strategic choices. 


\section{The International Journal of Human Resource Management}

For some time, the main aim of reform had been to stimulate competition by lowering the barriers to entry to newcomers. IOUs were fully integrated private monopolies, providing generation, transmission and distribution throughout the geographical areas they served. Since the New Deal era of the 1930s, they had co-existed with an array of other smaller players, including federal and municipal utilities and co-operatives in rural areas, introduced following spectacular market failures. The Public Utility Regulatory Policies Act (PURPA) 1978 obliged IOUs to buy surplus electricity from fuel-diverse independent power producers (IPPs) at the 'avoided cost', that is the price they would have to pay if they built the plant themselves. Competition was widened further by the Energy Policy Act 1992 (EPACT) which created another sub-category of non-utilities, the exempt wholesale generators (EWGs). From this point onward, restructuring initiatives strongly resembled those developed earlier in the UK, in broad terms at least. Transmission was separated from generation and from distribution (FERC Order 888, April 1996). New market entrants were to be given access to the distribution system and permitted a direct interface with retail customers.

Quests for economies of scale and scope Restructuring disturbed the predictable trading environment in the industry. Business strategies began to emphasize growth as the best form of defence, or as one executive reportedly put it, 'get big or get out' (Interview notes). Mergers and acquisition activity in the USA increased significantly, but continuing regulation of IOUs meant this was not a straightforward process and this forms an important part of the explanation for increased overseas investment.

Contrary to the stereotype of the USA as a liberal market economy, the electricity industry is highly regulated and regulatory authorities have shown particular interest in company growth strategies. In the early years of the industry, IOUs attempted to obviate state-level regulation by developing cross-state holding companies. Subsequent federal legislation (the Public Utilities Holding Company Act 1935) gave critical roles to the Securities and Exchange Commission (SEC) and the Federal Power Commission, renamed in 1997 the Federal Energy Regulatory Commission (FERC). Regulation included setting of wholesale prices to industry by FERC; setting of retail prices by state commissions; requirements for financial disclosure and rate of return regulation; restrictions on diversification and horizontal integration (e.g. into oil or gas exploration); and prior approval of mergers and acquisitions. SEC regulates financial transactions within holding companies and is empowered to require divestments and to confine companies to activities appropriate to a utility company.

One domestic merger, between AEP and CSW, illustrates the impact of American domestic regulation: it took over 3 years to complete and required agreements with unions, wholesale customers, and state regulatory bodies in Indiana, Kentucky, Missouri and Ohio (PR Newswire, 1999: 1823). Companies had long developed international business streams, mainly in Central and South America. In the context of restructuring in the USA, they began to look for growth potential further afield. Prior re-regulation in the UK made growth through acquisition there a comparatively flexible and fruitful option.

\section{Factors pulling American firms towards the UK}

The UK electricity industry was 'open for business' In contrast to preceding privatization initiatives in the UK, which had been criticized for simply passing public monopolies intact to the private sector, re-regulation of the electricity industry was marked initially by a determination to break up monopoly supply. This dual need, 
to secure additional investment while preventing re-integration, was to provide quite strong incentives for foreign direct investment.

Re-regulation was achieved by separating generation, transmission and distribution (Bromley, 1996). Generation capacity vested in the nationalized Central Electricity Generating Board (CEGB) was sub-divided to create three distinct generating companies, National Power, Powergen and British Energy. The National Grid assumed responsibility for transmission of power from the generators which was then distributed to end users by the 12 regional electricity companies (RECs).

Changes of ownership were achieved for generation and for distribution almost immediately after the Electricity Act 1989 (Electricity Association, 2003). Powergen and National Power were floated on the stock exchange in 1991. Nuclear capacity was vested in British Energy, which was to follow in 1996. Initially the National Grid was owned jointly by the 12 RECs (these had been floated in 1990) but this too was destined for private and independent ownership by 1995 .

Competition policy in the UK between 1992 and 1997 provided strong incentives to inward investors. To spread market share and encourage competition, the big generating companies were required to divest capacity. American companies showed particular early interest in buying and constructing power stations. More critically, corporate strategies that appeared to permit vertical or horizontal re-integration between domestic companies were viewed with suspicion. When Powergen bid for Midlands Electricity in 1995, government referred the issue to the Monopolies and Mergers Commission. Soon after, National Power was also referred following its bid for Southern Electric and both bids were blocked the following year. Confining the national champions in this way effectively gave the green light to other prospective inward investors. The rush from America particularly should be understood in this light. The month after Powergen's bid for Midlands Electricity was finally blocked (April 1996), GPU and Cinergy tabled a joint bid from the USA for the company and a further six American companies made bids for UK companies within a year.

American companies came to develop new income streams The perceived need to grow was accompanied by a hunger for new income streams and a reasonable expectation that this would be satisfied in the UK. Net annual income from North American domestic markets went into decline during the mid-1990s while operating costs increased (EIA, 2001). Yet the scope for earnings growth in the USA remained relatively modest, due once again to regulation. Setting of price controls was a more protracted and intensive process than in the UK and one informed throughout by designedly democratic mechanisms. IOUs were required to notify relevant commissions of any proposal to alter tariff structures. Commissions were obliged, in turn, to initiate public consultation during which interested parties, including individual households, had rights to examine financial statistics, question IOU executives and make representations to the commission.

By contrast, the newly re-regulated UK environment permitted initially very generous returns, precisely to encourage new investment and ensure the success of privatization. The 'pool' market for wholesale electricity, initially provided strong financial incentives since prices remained significantly above the costs of entry (OECD, 2002: 18). Average returns on investment increased from 4 per cent at the time of privatization to 11 per cent in 1996 (Parker, 1999: 218). Even in the regulated distribution sector, price caps allowed generous returns; 'government was keen to ensure that caps were not set so as to deter potential investors' (Parker, 1999: 219). In the 3 years to 1995, turnover in the industry rose by just 2.3 per cent but profits increased by 39 per cent (Unison, 1997: 23). This is the backdrop against which the substantial inflow of American investment began. 


\section{The International Journal of Human Resource Management}

American companies came to 'learn the ropes' in a re-regulated environment A key factor behind American investment in the UK was its vanguard position as the first country to re-regulate electricity supply, and the one that had gone the furthest to usher in competition (McGowan, 1994). Companies that were still relatively integrated wished to learn about operations in markets where activities had been 'unbundled' by statute. Those focused on generation wanted to learn about production for 'spot markets' for wholesale electricity. More generally, experience of Britain's 'light touch' system was useful as a guide to possible domestic environments in the future, as well as for the intrinsic financial rewards it appeared to offer.

Market developments in the UK have been shaped strongly by government and by the regulator. The Office of Electricity Regulation (OFFER), subsequently to be subsumed within the Office for Gas and Electricity Markets (OFGEM), has an industry-wide duty to eliminate anti-competitive practices. The full force of regulatory intervention is felt in the transmission and distribution areas. In contrast to regulation in the USA, OFGEM and its predecessor pioneered exclusive reliance upon price cap regulation (EIA, 2000a; Green, 1997). It is said to increase efficiency by requiring closer and constant internal reviews of the balance between the cost of resources and the income they generate in the form of prices paid by customers. Because it requires less detailed information, in theory at least, price cap regulation is said to permit lighter touch, less bureaucratically driven regulation without weakening the hand of the authority vis-à-vis the incumbent operators.

American companies came to gain a foothold in European markets Finally, the most ambitious and internationally aggressive companies were quick to place UK acquisitions in the context of long-term plans to diversify further into Europe. An EU directive in February 1999 required states to open competition for at least the top 26 per cent of industrial and commercial customers. By the end of 2000, 75 per cent of Europe's power markets were notionally open to competition (Financial Times, 26 June 2001: 2). European markets were important in their own right, but they often offered access to additional markets via the legacy of colonial investment, for example from the Spanish utilities into Latin America (Daly, 2001: 11). American companies, such as AES, quickly acquired generating capacity in Eastern Europe and the Netherlands. TXU established electricity trading functions in Geneva, acquired companies in Eastern Europe, and made bids in Spain and Germany.

\section{Push and pull: the contingent nature of American investment}

Strategic intent among some companies to play the long game and break into European markets was mixed with generally opportunistic motives to deepen short-term returns. Given that these companies were relatively new to trans-national operation, or transatlantic operation at any rate, investment could easily be threatened if any of these prizes failed to materialize.

And so it proved. Returns on investment were threatened soon after the change in government in 1997. The prospering privatized utilities were a key target for the incoming Labour government. While popular attention focused on the one-off 'Windfall Tax' on company profits, an arguably more significant initiative was the review of regulation in the sector. The consequent Utilities Act 2000 changed the composition of the regulatory body and amended its mandate to ensure that the needs of consumers were paramount, rather than merely balanced with those of the industry as previously (Cooper, 2000; OECD, 2002: 23). Price reviews after 1997 began to reduce aggressively the 
handsome rates of return available earlier. The act also introduced new trading arrangements for wholesale electricity, which played a part in driving down prices by 40 per cent over 4 years (Boyfield, 2002: 18).

European markets also proved harder to break into than British ones. In contrast to policies in the UK, which had the effect of inviting inward investment, France and Germany protected their domestic markets while their national champions restructured (Birchall, 2001). In Germany, the giant Eon was formed in 1999 following merger between Veba and Viag. Restructuring endowed European companies with strength to rebuff American competition at home, and the resources to expand abroad. Eon, for example, was able to finance acquisition activity without borrowing, through the sale of non-core businesses and was subsequently to takeover Powergen and Midlands Electricity in the UK. Electricite de France (EdF) took on London Electricity and South Western Electricity.

By contrast, from 2000, it became clear that US companies had over-extended their credit to pay premium prices for British companies and wished to sell-on their UK interests. Generators like AES and Entergy were forced to renegotiate debts and/or cut their losses by selling assets. By 2003, only four American companies remained in UK distribution and several American-owned power stations had been sold or were on the market. The American takeover of the British electricity industry was not to be a longterm event.

\section{Second-order effects: explaining organizational forms}

Our argument is that these first-order effects explain to a large extent management orientation and employee relations in American-owned electricity companies. Turning to second-order effects, organizational form was determined substantially by coercive isomorphism stemming from formal governance imposed by the UK regulator. Particularly within the distribution companies, where the regulator had the most impact, this also conditioned tendencies towards mimetic isomorphism. That is, when dealing with this new set of regulatory issues, managers drew primarily on the recipes used successfully elsewhere in the sector. Given the first mover position of the UK in privatization, this tended to mean the privatized British utilities. Some attempts were made to instil archetypal 'American' management styles and values, but these were outweighed generally by the objectives of exploiting new income streams and 'learning the ropes', which were reflected in 'hands-off' approaches to UK operations.

Companies moved increasingly to $\mathrm{m}$-form or business stream approaches in which distribution, supply and generation business are managed separately. At the same time, many took the opportunity to drive through savings by stripping out corporate functions, including human resources departments, and devolving these to business streams. One officer recalled developments in the American-owned company for which he held negotiating responsibilities; 'where before they had a big finance department, a big HR department, they stripped those right down. If I remember rightly, it went from about 140 odd down to about 30.'

Since the multi-divisional form was pioneered by American companies, this looks superficially like a consequence of changes in ownership and subsequent home country influences. It would also be complementary to increased home country influence, since it might provide greater scope for co-ordination from corporate functions in the USA. But regulatory requirements are reported to have been the key influence on company structure, particularly in distribution companies. Intervention from the regulator in the 1990s required complete separation of retail (shops selling electrical goods) from core 


\section{The International Journal of Human Resource Management}

businesses. Subsequently, companies also had to 'unbundle' the various aspects of their core distribution and supply businesses. Distribution involves maintenance of overground and underground cables. The direct interface with the customer is handled through supply businesses, including meter reading and customer call centres. Unbundling generally involved their separation into distinct businesses and the devolution to them of previously corporate support functions. As one union officer observed: 'this is driven by the ... commercial logic of the industry and the regulatory logic, it's not driven by any other extraneous factor. It's happening regardless of who the owner is.'

Turning to changes in management style, there had been few attempts by American owners to 'colonize' management structures. Expatriation of US managers was not a marked feature within electricity supply. The appointment of senior American managers to key posts was reported in only two companies. The general orientation described to us was 'hands-off' with key posts retained by British managers. American presence tended to be a minor and often ephemeral phenomenon, focused around the initial acquisition. One union officer noted of Americans in his company, 'we never see them'. Another thought the principal modus operandi was, 'you carry on managing, we will stay in the background. As long as you hit our targets, maintain our profits, make sure our turnover is OK, you carry on.' Financial targets were reportedly the only significant performance indicator insisted upon by American owners: 'they're given a bottom line objective, and that's about it. And they say to me very clearly that they've found the American parent very, very free in terms of taking the advice of the local guy.' Another officer noted, 'to all intents and purposes, it is the managers of the two businesses that run the show now ... it never appears to be, "oh we have to go back and talk to Daddy".

In fact, the flow of management expertise tended to be from the UK back to the US, possibly reflecting the objective to 'learn the ropes'. One company's American owners, "said right at the outset, ".you have more experience of real competition than we have and we want your expertise". . In that company, distribution engineers in particular had been taken over to the USA, possibly providing the basis in time for reverse normative isomorphism, at least in technical protocols. More senior British figures were also increasingly head hunted by American firms. Norman Askew, former Chief Executive of East Midlands Electricity was appointed CEO of Virginia Power (interview notes) and Roger Young was recruited from Scottish Hydro Electric to FPL Group in Florida (Financial Times, 18 December 1998: 16).

These factors did not preclude altogether the emergence of American management styles and it is important to note that these were in evidence. At a superficial level, one company renamed their Managing Directors, Executive Presidents and their senior managers, Vice Presidents. Revised mission statements often seemed to reflect, and to be designed to diffuse, an American ethos. Documentation obtained from one company described, 'our business style' under eight headings, which included, ethical behaviour, customer first, business awareness ('we think like customers and act like owners'), great place to work ('we are a first name company'), teamwork, superior performance, leadership and citizenship. Some specific initiatives were perceived by employees as having distinctly American overtones. One company had introduced a 'Drugs and Alcohol Policy' with a markedly aggressive stance manifest in the total prohibition of drinking and an insistence on management's right to conduct random blood sampling. Reportedly, only soft drinks were served at the company's Christmas party and the brandy sauce contained only artificial flavouring. As one union representative put it, 'some American directors are alcoholics, others are bible bashers. We got the bible bashers.' 
Although acknowledging particular inflections stemming from American ownership in these cases, other respondents advised against detecting the exclusive operation of home country influences. General trends towards the introduction of drug and alcohol policies had been apparent in the UK since before privatization, with the full support of unions: 'we can't condone people in charge of these sorts of products being sozzled'. What was new was the extension of these policies from engineering and industrial staff to those working in office environments, something attributable to harmonization following single table bargaining, rather than the novel preferences of particular owners. This brings us to third-order effects on employment specifically.

\section{Third-order effects: ramifications for employment}

In this section, we deepen the focus on the employment consequences of American ownership, focusing on three areas characteristic of industrial relations in the US. Following the line of argument so far, these are found not to be a far-reaching influence in the electricity industry. American managers, concerned more with first-order issues, maintained 'hands-off' approaches to employment for the most part. Even in those cases where home country influence was apparent, the source and form of change followed patterns broadly similar to those occurring across the industry.

\section{Employee relations}

We focus first on the most critical single issue, the overall orientation towards relations with the workforce. Unions had been woven deeply into the fabric of the nationalized British electricity supply industry in two senses. First, the machinery of negotiation and consultation was formalized and centralized and offered detailed influence to unions over management of the industry. Changes to work processes for manual staff, including any affecting, 'the organization, the supervision, the materials and the equipment' (National Joint Industrial Council agreement, quoted in Ferner and Colling, 1993: 107), were subject to formal consultation locally and possibly at national level, in the event of a local disagreement. Second, 'working' this system encouraged very close relationships between union officers and managers at every level in the industry. Much of the actual negotiation affecting formal outcomes was conducted in 'good offices' meetings outside of the industrial relations machinery (ibid.). This machinery, and the workplace cultures that it fostered, had changed by the mid-1990s, particularly as a consequence of decentralized bargaining but strong residues remained.

By contrast, American companies are famed in general for hostility towards collective relations and organized labour and these preferences have often been transferred to multinational subsidiaries. Significantly, many of the electricity companies internationalizing most aggressively came from the southern states where anti-unionism historically was most pronounced. But the specific dynamics of the electricity industry, particularly the sustained influence of New Deal regulation, offered American unions a stake unavailable in recent years across the American economy more generally. Unusually, therefore, when thinking about home country influences, companies coming into the UK had experience of collective relations in the USA but differences in their tenor were pronounced. British union officials forging links with their American counterparts were struck forcefully by the deeply adversarial nature of industrial relations, and contrasted this with the 'partnership' approaches pursued generally in the UK. Union organization in the USA was also a tightly confined affair, with supervisors and managers being expressly excluded, as is generally the case there. Strong contrasts 


\section{The International Journal of Human Resource Management}

with the UK were drawn once again, since management grades had been very well organized here and supervisory relations subject historically to joint regulation.

American-owned companies did seize opportunities to narrow collective channels. Attempts apparently to replicate the total exclusion of collective bargaining from management grades pressured the EMA in particular, whose membership constituency fell precisely among such groups. In two companies, management placed all managers and engineering staff on personal contracts, subject to individual performance-related pay rather than collective bargaining. More wide ranging, and potentially aggressive initiatives were also reported. Early meetings between unions and one new American owner were observed by a former American union official, apparently retained by the company as a 'union buster'. One generating company espoused an individualistic ethos that spilled over into active union avoidance. A station manager invited to attend a branch meeting of the EMA told his audience that in the future he would regard it as a 'failure' if unions were to be involved in the company 'at any level' (EMA Internal Correspondence, December 2000). Unions generally reported that their contact with managers had been downgraded significantly. Lay representatives in one company noted that their employers liked to get collective bargaining out of the way as quickly as possible, and for as long as possible. A series of quickly conceded 2-year deals reduced the profile of the union in the company during interim periods. Perhaps the starkest illustration of diminished union influence, though, came in the response of one company to one of the regulator's more aggressive price reviews following the change in government. Managers used a hastily convened evening meeting with union officials to announce the creation of a joint venture with a neighbouring distribution company, which would result in the transfer of employees and some redundancies. The initiative was announced to the press the following morning and redundancy notices issued immediately. For negotiators used historically to advance detailed scrutiny of management plans, developments of this kind were startling.

However, there are some important qualifications to this general impression. First, union respondents traced even the most hostile industrial relations initiatives to British managers rather than American ones. The transfer of all management staff to personal contracts in one distribution company, mentioned above, was explained by long-standing tensions between the lead manager and the EMA. In another case, proposals to rationalize the recognition agreements (and to derecognize two unions with marginal memberships) came from a newly appointed British manager. Described by one union official as 'a black shirt', he had been recruited from the ferry industry, where antiunion stances had been demonstrated forcefully in disputes during the 1980s.

Second, the isomorphic field tended to cohere around successful UK utilities rather than American ones. The blanket shift to personal contracts for all engineering staff noted in two American companies was markedly comprehensive, but the trend among management grade engineers was very long established and began almost immediately after privatization (see Ferner and Colling, 1993). Similarly, the most significant shift in bargaining relationships, from national to company level, followed the break-up of national bargaining immediately after privatization. At that stage, several companies moved to introduce single table bargaining, including Norweb, Northern Electric, Powergen, Southern Electric, SWEB, Midland and National Grid (Gall, 1994: 64). Broader sector-level influences across the British utilities were at play here, since this followed a similar trend earlier in the UK water industry. Derecognition of unions with marginal membership was a feature of such transitions but generally was not repeated afterwards. Similarly, the shift to 2-year pay deals was general across the industry and 
involved the two major British generators, National Power and Powergen, as well as American firms.

Third, union avoidance was highly contingent and had definite limits. For one set of unions, new bargaining arrangements that challenged their organization coincided with invitations from executive managers to take a more prominent role in the public presentation of the company than previously. Recruitment of new members received an unexpected fillip when unions were permitted to set up stalls at the company's open day: 'It is mega, it is huge... and that was very, very successful for us.' When the same company began to acquire power stations from existing suppliers, manual unions were offered recognition agreements where none had existed before and invited to negotiate the harmonization of terms and conditions for those transferring to the company.

In most cases, then, American owners deployed a 'hands-off' approach to employee relations, permitting British managers to develop specific strategies subject only to the broad imperatives of maintaining earnings flows and the reputation of the parent company.

\section{Employment security}

In the American utilities, principles of 'employment at will' had been manifest in largescale job reductions which had become more pronounced towards the end of the 1990s (UWUA, 2000). The major investor-owned utilities cut employment by a third, from around 520,000 to 340,000 in the 12 years to 1998 (EIA, 2000b).

Similar approaches were manifest among American electricity companies operating in the UK. Ownership change resulted often in searches for efficiency savings and cuts in employment and some companies demonstrated an unusually hard edge when effecting redundancies. Commonly, structural adjustments in the workforce had been eased in the UK by generous voluntary severance schemes but union officers observed deep intellectual struggle in the American executives to whom they had to explain this: "the culture back there is, "well things go down the pan; it is for you to sort yourself out". It is not for the employer to pay out large amounts of money if they want to close down part of a business.' In an apparently noteworthy instance of this kind of approach, a distribution company announced that 500 employees would be made redundant on Christmas Day, on statutory terms only (Morgan, 1999).

Once again, though, it is important to contextualize this apparent home country effect. Union officers emphasized that, in making job cuts, American companies were only swimming with the flow of employment trends already very well established in the UK. Labour shedding became a sustained feature of the UK electricity industry long before American investors arrived. A pre-privatization workforce of around 150,000 was halved during the 1990s and cuts of more than a third were made in the first 5 years following privatization (Arrowsmith and Edwards, 2000).

Employment reduction is attributable to structural changes in the industry common to all companies, regardless of ownership. In generation, for example, particularly marked reductions were achieved as a consequence of subcontracting power station maintenance and the replacement of older generating capacity. Powergen's workforce was cut by more than 50 per cent, from 9,000 in 1990 to 3,700 in 1995 (Arrowsmith, 2003: 154). The proliferation of gas turbine plants facilitated restructuring since these smaller, more efficient stations can be very lightly staffed. In distribution, regulation was the common prompt to labour shedding (Bannister, 1999, 2000). Price reviews conducted under newly tightened criteria after 1997 built in assumptions about optimal staffing levels, based on benchmarked data commissioned from consultants. Cost differences between actual and 


\section{The International Journal of Human Resource Management}

assumed optimal employment levels were then factored into potential cost savings to determine the retail price chargeable by companies. This framework did not determine the extent of job cuts in any mechanistic way. Union respondents reported the position of the regulator as being, 'they're just a mechanism to get into my price figure. Once the price is there, it's up to the companies to manage any way they like.' There is little doubt, however, that consequent reductions in income streams occasioned job loss and that the assumptions used by the regulator shaped its extent. In 1999, five distribution companies simultaneously announced job cuts totalling 2,500 (The Guardian, 19 November 1999).

One question then arises, did the American companies manage this general pressure in any distinctive way? The example cited above, of a company announcing compulsory redundancies to take effect on Christmas Day, appears to provide an instance of a particularly American approach to employment reductions. But one senior union respondent closely involved with executive-level attempts to defuse the situation pointed to a critical distinction. Managers' objectives were not third-order ones, focused on employment; they were concerned with first-order issues related to investment returns and the regulatory processes governing these. The distribution area of the company contained the constituencies of leading figures in the Labour government. Thus, a local outcry was provoked in the hope that these figures would press the regulator to reconsider the price review. When it became clear that this was not possible, the company softened its position on the redundancies and negotiated an entirely conventional package of voluntary measures. As the union official put it, 'It was nothing to do with industrial relations, we were the pigs in the middle... [The American Chief Executive] actually said to me at one stage, "what kind of country is this where you can't put pressure on your regulator" - he actually said that!'

\section{Pay}

Key indicators of American approaches to employment include individualized approaches to pay and attempts to link reward to performance. Both were in evidence in the electricity industry during this period but their extent should not be exaggerated and, once again, neither should their incidence be attributed straightforwardly to American influence.

Highly structured and hierarchical pay systems at the time of privatization were changed through the 1990s and there was some evidence that American influence hastened the process. In the run-up to full deregulation of domestic markets, as customer retention became an issue for distribution companies, at least one American-owned company introduced performance-related pay schemes based on others run successfully in the USA (IDS, 1996: 27). Bonuses were triggered when the proportion of customers reporting themselves 'very satisfied' passed a specified point.

But evidence that American companies were leading any vanguard movement on the pay issue is scarce. In terms of overall settlement levels, between 1996 and 2003 American-owned firms reached agreements more or less in line with the industry overall (IDS, various), with inflation plus deals being the norm. In 2000, average pay settlements dipped below inflation for the first time since deregulation. Inflation plus deals resumed shortly afterwards and bunching around the median became still more marked from that point (IRS, 2000: 6, 2003: 23).

Innovation in the composition of pay was also relatively muted. Contingent pay was predominantly profit-related, available to around half of all bargaining groups in the industry. Performance-related bonuses comprised a relatively small proportion of pay overall; a maximum of $£ 100$ per annum was payable in the American influenced example 
cited above (IDS, 1996: 27). Interview data suggested that their scope was similarly confined with schemes opened mainly to managers, as a consequence of personal contracts, and to relatively small, 'customer-facing' groups of staff in areas such as sales, power trading and meter reading.

Where it occurred at all, the impetus behind pay reform was not generated especially by American-owned firms. An incident recalled by one union respondent is suggestive of a lack of articulation between pay policies pursued in the USA and in British subsidiaries. A relatively rare example of British employees being exposed to American corporate culture, in the form of a briefing video, produced some mistaken excitement when it was announced that,

'every one of our employees will receive a $\$ 500$ Christmas bonus' but they didn't mean [British subsidiary] employees! (laughs). They all went, 'wow!' but the managers said, 'oh no, they don't mean you!' It was like the global corporate video, which they showed to everybody, but how much of it was relevant to [the British subsidiary] was questionable. It becomes a bit of a joke I suppose.

Rather, the strongest influences appeared to come from host country sector and regulatory effects. A British firm, National Grid, was prominent among those pioneering shifts to merit pay, for example (IRS, 1997: 11). For many union officers, the process had extended from the other utilities, especially the water industry, where reform was generally further advanced. One had recently negotiated a competency-based pay system, 'but it would be unfair to say that is only because the Americans are there because it is happening in every utility I deal with anyway'. Once again, the regulator was singled out as the principal shaping influence in the industry. One senior officer attributed the growth of contingent pay to regulatory influence: 'the regulator has been arguing that companies have to be in complete control of costs. And so, I think some of the arguments used in some of the companies are that people only get pay improvements if they perform.' Regulatory influence certainly conditioned pay growth overall, particularly during the price reviews from 1999. Costs calculations used in the process were constructed from benchmarking on employment levels, as mentioned above, and also pay data. Union respondents felt strongly that this effectively allowed management consultants to set pay levels indirectly: 'no consultation, no negotiation, no nothing. The consultants say that's what it should be.' Such complaints were addressed in terms to the regulator directly.

The New Earnings Survey was apparently used to benchmark terms and conditions. We would like to know how... As trade union officials, we have very wide experience of salary surveys and considerable scepticism about most. There is no evidence to show that the New Earnings Survey is any more reliable than any other survey and this is particularly a problem when we do not know how that information was used (Electricity Supply Trade Union Council, undated).

As with employment levels, evaluations used during the review process could not determine pay outcomes, the regulator had no authority to insist on those being held at particular levels. In such a capital-intensive industry, however, wage costs are a high proportion of controllable costs. Price reductions required on the assumption that wage costs could be reduced inevitably prompted close scrutiny of pay norms as a means of reestablishing profit streams in a newly hostile environment. This much was evidenced by the drop in median pay settlements immediately after the reviews, noted above.

\section{Conclusions}

Our point of departure here has been to investigate patterns of employment change occasioned by American investment in the British electricity industry. Multinational 


\section{The International Journal of Human Resource Management}

companies develop first in their home country environments and values and instincts developed there are likely to condition approaches to the management of international subsidiaries. American companies are famed generally for their centralized management structures and for preferences for individualized employee relations, performancerelated pay, and unencumbered managerial discretion over workforce reductions. Trends in each of these directions are apparent in the findings discussed here, but qualitative evidence on the genesis and implementation of these processes suggests strongly that specific American influence was not decisive where it was a factor at all. How can the weakness of country of origin pressures in this instance be explained?

One obvious response would be that the period in question was so short. Acquisitions made from the mid-1990s were being sold on again shortly afterwards. Arguably, it is not realistic to expect to find strong home country effects being demonstrated in the space of just 5 or 6 years. But this would miss the point, which is that the findings require that we explain the contingent nature of the investment and how this conditioned approaches to employment. It is this task that draws us to consider the role of sector specific pressures and their operation across borders.

At the outset of the paper, three questions were posed about the sector level influences and we return to these now in the light of our findings. First, under what circumstances are sector effects communicated trans-nationally? The question needs to be set against findings from a long line of studies showing the importance of country of origin as an influence on multinational companies, and strong differences between firms from different national contexts operating in the same sector. The qualitative findings discussed here suggest a nuanced picture, in which similar developments in national regulation were prompting international integration and providing emergent pressures towards isomorphism. From this point of view, they echo other studies detecting isomorphic effects in sectors which are integrated cross-nationally by similar patterns of technology, organization and/or regulation. Woywode (2002) discovered similar trends towards teamworking in the car industry, for example, and common strategies have been highlighted in civil aviation (Martinez-Lucio et al., 2001), albeit with scope for continuing differences in implementation in both cases. In this case, the isomorphic pressures are highlighted starkly by the nature and timing of the investments. Regulatory developments pushed American firms to consider international expansion, and pulled them towards the UK specifically, where they could expand asset bases and income streams relatively easily and learn about operations in a re-regulated environment. Such a context provided plenty of scope for coercive, mimetic and normative isomorphism across national boundaries.

This takes us to the second of the three questions; what consequences do sectoral pressures carry for the management of employment? Except in some very broad senses, the sectoral pressures identified here did not impact directly on employment. It is true that both American and British companies tended historically to be unionized, for example, and quite radical employment reductions had been common in both countries more recently. These factors can be explained by underlying characteristics fundamental to the sector. Given the strategic importance of the product, government and employers in both countries shared an interest in maintaining ordered industrial relations and employment change is attributable substantially to changing technologies, particularly the shift away from large coal-fired plant in generation. It certainly seems likely that emergent similarities in the regulation of the respective domestic sectors will reinforce these employment characteristics and the extent to which they are shared across borders. But the detailed findings discussed here uncovered important differences between the two settings that leave room for substantially divergent approaches. Patterns of unionization 
were markedly different, particularly in relation to management and technical staff, and American approaches to employment reduction were instinctively harder edged than British ones.

Finally, we set out to consider how cross-national employment trends are influenced by the structural and normative frameworks provided by national business systems. Isomorphism operated at levels above third-order decision-making over employment. American owners were concerned principally with first-order decisions over investment and the regulatory context, and some second-order ones around organizational structure. On employment relations strategies, there were strong findings of coercive and mimetic isomorphism but the field tended to be localized. Almost regardless of ownership, underlying regulatory pressures created markedly similar approaches across the British electricity sector. American owners tended to allow their British managers to interpret and adapt these local trends.

Thus developments in the electricity industry highlight the complexity of decisionmaking in multinational companies and the interaction of a range of factors at different levels. In contrast to several studies, country of origin characteristics did not condition management preferences to any significant degree, particularly in relation to employment relations. This can only be understood in the context of similar developments in sector level governance in both countries, and the processes through which this drove international strategies at higher levels, affecting investment and organizational structure. This constellation of factors produced a tendency to comply with host country isomorphic pressures rather than challenge them.

\section{Acknowledgements}

We are grateful to the trade union officers and representatives that supported this research so generously, responding to our queries with patience and candour. Thanks also to Anthony Ferner and to the editor and referees of this journal for comments on earlier drafts of this paper. Responsibility for any errors remains of course with us.

\section{Note}

1 Data considered here were generated during fieldwork exploring human resource management in multinational companies, supported by the Economic and Social Research Council (award number R000238350). The project team consisted of Phil Almond, Peter Butler, Ian Clark, Trevor Colling, Anthony Ferner, Len Holden and Michael Muller-Camen (all then at De Montfort University, Leicester) and Tony Edwards (Kings College, London).

\section{References}

Arrowsmith, J. (2003) 'Post-Privatisation Industrial Relations in the UK Rail and Electricity Industries', Industrial Relations Journal, 34(2): 150-63.

Arrowsmith, J. and Edwards, T. (2000) 'Industrial Relations Implications of the Liberalisation of the UK Electricity Sector'. Eiro Online. Online at: http://www.eiro.eurofound.ie/2000/12/ features/uk0012105f.html

Arrowsmith, J. and Sisson, K. (1999) 'Pay and Working Time: Towards Organisation Based Arrangements?', British Journal of Industrial Relations, 37(1): 51-75.

Bannister, N. (1999) '330 Electricity Jobs Lost to Meet Target', The Guardian, 16 October, online at: http://www.guardianunlimited.co.uk/archive/article/

Bannister, N. (2000) '1,350 More Jobs to go in Water and Power', The Guardian, 18 January, online at: http://www.guardianunlimited.co.uk/archive/article/ 


\section{The International Journal of Human Resource Management}

Birchall, J., 'French Criticised Over Power Market' Financial Times, 24 January, online at: http:// www.globalarchive.ft.com/articles.html

Boyfield, K. (2002) 'Americans Fly', Utility Week, 1 November: 17-18.

Bromley, S. (1996) 'Energy'. In Coates, D. (ed.) Industrial Policy in Britain. Basingstoke: Macmillan, pp. 85-112.

Coates, D. (2001) Models of Capitalism: Growth and Stagnation in the Modern Era. Cambridge: Polity Press.

Colling, T. (1991) 'Privatisation and the Management of Industrial Relations in Electricity Distribution', Industrial Relations Journal, 22(2): 117-29.

Cooper, J. (2000) 'Regulation But Not As We Know It - The Utilities Bill', New Law Journal, 150(6926): 352.

Daly, E. (2001) 'Spain's Electric Growth Spurt: Foreign Suitors Size Up Country’s Main Power Companies', Herald Tribune, 17-18 February: 11.

DiMaggio, P. and Powell, W. (1983) 'The Iron Cage Revisited: Institutional Isomorphism and Collective Rationality in Organizational Fields', American Sociological Review, 48: 161-73.

Edwards, T. and Ferner, A. (2002) 'The Renewed American Challenge: A Review of Employment Practice in US Multinationals', Industrial Relations Journal, 33(2): 94-111.

Electricity Association (2003) Who Owns Whom in the UK Electricity Industry. Policy Research, 30 June, London: Electricity Association.

Electricity Supply Trades Union Council (ESTUC) (Undated): Distribution Review Draft Price Controls: Submission by the Electricity Supply Trades Union Council.

Energy Information Administration (EIA) (2000a) Electricity Reform Abroad and US Investment, US Department of Energy. Chapter 1: 'Electricity Reform Abroad: Experiments in Argentina, Australia and the United Kingdom', online at: http://www.eia.doe.gov/cneaf/emeu/pgem/ electric/ch1.html

Energy Information Administration (EIA) (2000b) Transitional Strategies, US Department of Energy, online at: http://www.eia.doe.gov/cneaf/electricity/chg_str/booklet/strategies.html

Energy Information Administration (EIA) (2000c) The Changing Structure of the Electric Power Industry 2000: An Update, US Department of Energy, October, online at: http://www.eia.doe. gov/cneaf/electricity/chg_str_update2000.html

Energy Information Administration (EIA) (2001) Financial Statistics of Major US Investor Owned Electric Utilities, US Department of Energy, online at: http://www.eia.doe.gov/cneaf/ electricity/invest_sum.html

Ferner, A. (1997) 'Country of Origin Effects and HRM in Multinational Companies', Human Resource Management Journal, 7(1): 19-37.

Ferner, A. and Colling, T. (1993) 'Industrial Relations in the Electricity Supply Industry'. In Pendleton, A. and Winterton, J. (eds) Public Enterprises in Transition - Industrial Relations in State and Privatised Industries. London: Routledge.

Ferner, A., Almond, P., Clark, I., Colling, T., Edwards, T., Holden, L. and Muller-Camen, M. (2004) 'The Dynamics of Central Control and Subsidiary Autonomy in the Management of Human Resources: Case Study Evidence from US MNCs in the UK', Organization Studies, 25(3): 363-91.

Gall, G. (1994) 'The Rise of Single Table Bargaining in Britain', Employee Relations, 16(4): $62-71$.

Green, R. (1997) 'Has Price Cap Regulation of UK Utilities Been a Success?', Public Policy for the Private Sector, The World Bank, Note no.132, online at: http://www.worldbank.org/html/fpd/ notes $/ 132 /$

Gow, D. (1999) 'Industry Attacks Power Pool “Gaming”', The Guardian, 21 July, online at: http:// www.guardianunlimited.co.uk/archive/article/

Gow, D. (2000) 'Grid Turns Its Back on UK', The Guardian, 24 May, online at: http://www. guardianunlimited.co.uk/archive/article/

Hall, M., Hoffman, A., Marginson, P. and Muller, T. (2003) 'National Influences on European Works Councils in UK and US-Based Companies', Human Resource Management Journal, 13(4): 75-92. 
Colling and Clark: Exploring trans-national sector ... employment relations 1643

Hall, P. and Soskice, D. (2001) Varieties of Capitalism: The Institutional Foundations of Comparative Advantage. Oxford: Oxford University Press.

Harzing, A.-W. (1999) Managing the Multinationals: An International Study of Control Mechanisms. Cheltenham: Edward Elgar.

Harzing, A.-W. and Sorge, A. (2002) 'The Relative Impact of Country of Origin and Universal Contingencies on Internationalisation Strategies and Corporate Control in Multinational Enterprises: Worldwide and European Perspectives', Organisation Studies, 24(2): 187-214.

Heller, R. (2001) 'The Scots are Coming!', Forbes, 22 January: 76.

Hollingsworth, J.R. and Streek, W. (1994) 'Countries and Sectors: Concluding Remarks on Performance, Convergence, and Competitiveness'. In Hollingsworth, J.R., Schmitter, P.C. and Streek, W. (eds) Governing Capitalist Economies: Performance and Control of Economic Sectors. Oxford: Oxford University Press, pp. 270-300.

Incomes Data Services (IDS) (1996) 'SWEB Introduces Customer Satisfaction Bonus Based on US Model', IDS 716, July: 27-8.

Industrial Relations Services (IRS) (1997) 'Electricity, Gas and Water', Pay and Benefits Briefing, no. 437, December: 11.

Industrial Relations Services (IRS) (2000) 'Electricity, Gas and Water', Pay and Benefits Briefing, no. 508, November: 6 .

Industrial Relations Services (IRS) (2003) 'Energy and Utilities', Pay and Benefits Briefing, no. 788, November: 23.

Marginson, P., Hall, M., Hoffman, A. and Muller, T. (2004) 'The Impact of European Works Councils on Management Decision Making in UK and US-Based Multinationals: A Case Study Comparison', British Journal of Industrial Relations, 42(2), June: 209-33.

Maritinez-Lucio, M., Turnbull, P., Blyton, P. and McGurk, J. (2001) 'Using Regulation: An International Comparative Study of the Civil Aviation Industry in Britain and Spain', European Journal of Industrial Relations, 7 March: 49-70.

McGowan, F. (1994) 'The Internationalisation of Privatisation'. In Clarke, T. (ed.) International Privatisation: Strategies and Practices. Berlin: De Gruyter, pp. 25-42.

Morgan, O. (1999) 'Blackout Threat Over Job Cuts', The Observer, Business Supplement, 3 October: 1.

Muller-Camen, M., Almond, P., Gunnigle, P., Quintanilla, J. and Tempel, A. (2001) 'Between Home and Host Country: Multinationals and Employment in Europe', Industrial Relations Journal, 32(5): 435-49.

Negandhi, A. (1983) 'External and Internal Functioning of American, German and Japanese Multinational Corporations'. In Goldberg, W. (ed.) Governments and Multinationals. Cambridge, MA: Oelgeschlager.

Organization for Economic Cooperation and Development (OECD) (2002) 'Regulatory Reform in the United Kingdom'. OECD Reviews of Regulatory Reform. Paris: OECD.

Parker, D. (1999) 'Regulation of Privatised Public Utilities in the UK: Performance and Governance', International Journal of Public Sector Management, 12(3): 213-35.

Pendleton, A. (1997) 'The Evolution of Industrial Relations in the UK Nationalised Industries', British Journal of Industrial Relations, 35(2): 145-72.

PR Newswire (1999) 'Commonwealth Edison and Cinergy Withdraw as Intervenors in AEP-CSW Merger', 23 November: 1823.

Unison (1997) Deregulation of the UK Gas and Electricity Industries. Report prepared by Unison's National Energy Office for the Utility Workers Union of America Conference, 18-19 June. Washington, DC.

Unison (2000) Submission to the Office of Gas and Electricity Markets in Response to the Consultation Paper on the Joint Venture between Eastern Electricity and London Electricity.

Utility Workers' Union of America (UWUA) (2000) 'Fighting Deregulation and Protecting Utility Workers', online at: http://www.uwua.org/2991.html

White, M. (1996) ‘Tory Investment “Miracle” Attacked as Rich Pickings Sham', The Guardian, 30 December: 6. 
1644 The International Journal of Human Resource Management

Whitley, R. (1992) European Business Systems. Firms and Markets in their National Contexts. London: Sage.

Whitley, R. (2001) Divergent Capitalisms: The Social Structuring and Change of Business Systems. Oxford: Oxford University Press.

Woywode, M. (2002) 'Global Management Concepts and Local Adaptations: Working Groups in the French and German Car Manufacturing Industry', Organisation Studies, 23(4): 497-524.

Young, S., Hood, N. and Hamill, J. (1985) Decision-Making in Foreign-Owned Multinational Subsidiaries in the United Kingdom. ILO Working Paper no. 35, Geneva: ILO.

Yuen, E. and Kee, H.T. (1993) 'Headquarters, Host-Culture and Organisational Influences on HRM Policies and Practices', Management International Review, 33(4): 361-83. 